\title{
Nekroperformans. \\ O sprawczym oddziaływaniu szczątków w polskiej pamięci kulturowej
}

Dorota Sajewska

TEKSTY DRUGIE 2016, NR 6, S. 387-405

DOI: $10.18318 /$ td.2016.6.23

W spółczesna polska pamięć zdominowana jest przez dwa rywalizujące paradygmaty historiograficzne. Jeden z nich kształtują intensywnie rozwijające się studia nad pamięcią, w których kluczową rolę odgrywa teoretyczna konceptualizacja doświadczenia i traumy Zagłady. Drugi natomiast wyznacza matryca romantycznego ujęcia historii, zamykająca doświadczenie "polskości” w micie wyjątkowości oraz trwałym zestawie symbolicznych gestów, zachowań i rytuałów. Choć oba paradygmaty stoją - zarówno pod względem ideologicznym,jak i metodologicznym - w całkowitej sprzeczności, to łączy je swoista absolutyzacja doświadczenia ofiary oraz głęboko z nim związana koncepcja zranionej pamięci narodu - żydowskiego i polskiego. Można zatem powiedzieć, że pewne strukturalne podobieństwa między obiema formami pamięci, wynikające z przekonania o wyjątkowym i niepowtarzalnym charakterze z jednej strony Szoa jako wydarzenia historycznego, z drugiej zaś polskiej zbiorowości jako jedynej w swym rodzaju formy istnienia politycznego i kulturowego uniemożliwiają de facto współobcowanie obu paradygmatów we współczesnej Polsce.

\section{Dorota Sajewska}

(ur. 1975) - adiunkt w IKP UW, Assistenzprofessorin für Interart (Osteuropa) na Uniwersytecie w Zurychu oraz współpracowniczka Zentrum Künste und Kulturtheorie. Zajmuje się problematyką cielesności, medialności i polityczności teatru, zagadnieniami teatralności w innych mediach artystycznych i zjawiskami społecznymi, a także współczesnymi teoriami dokumentacji teatru i performansu. Kontakt: dsajewska@ gmail.com 
Ta niekomplementarna binarność obu modeli pamięci widoczna jest również we współczesnej historiografii teatralnej. Świadectwem tego przeciwstawienia są dwie, w moim przekonaniu, najwybitniejsze w tej dziedzinie książki ostatniego dwudziestolecia: Dziady. Teatr święta zmartych Leszka Kolankiewicza (1999) i Polski teatr Zagłady Grzegorza Niziołka (2013), stanowiące radykalne próby przepisania historii polskiej kultury przez pryzmat romantycznej obrzędowości z jednej strony i teatru Zagłady z drugiej. Wyprowadzona przez Kolankiewicza z pogańskiego obrzędu dziadów oraz antropologicznych odczytań polskich przedstawień i widowisk kulturowych koncepcja „Teatru święta zmarłych” stanowiła niewątpliwie awangardową i poniekąd bluźnierczą interpretację polskiej kultury i pamięci. Śledzenie kultu peryferyjnego, jego początków, losów i historii odbywało się bowiem w Dziadach Kolankiewicza poza religią centrum, prowadząc badacza do jawnego uderzenia w katolicyzm przez propozycję innego rodzaju religijności dzikiej, pogańskiej, barbarzyńskiej względem oficjalnej nauki Kościoła. Implicite zostało zatem wypowiedziane przekonanie, że polska historia teatru pozostawała dotąd nie tyle w polu oddziaływania oświeceniowego modelu uprawiania nauki, ile raczej że jej horyzont poznawczy był ograniczony dominującą w Polsce religią, nieuwzględniającą innych widowisk niż te zakorzenione w tradycji chrześcijańskiej. Wydobyta z polskiego romantyzmu peryferyjność sprawiła jednocześnie, że również narracja Kolankiewicza pozostała w kręgu oddziaływania romantycznego ujęcia historii. To właśnie romantyczne prawo partycypacji mistycznej pozwoliło badaczowi na podniesienie kultury ludowej do rangi mitu polskości i powtórzenie przekonania Marii Janion o konieczności wejścia do Europy „z naszymi umarłymi”. Wspólnota żywych i martwych stanowiła tu bowiem fundament obrzędowości i to w obrzędzie dziadów urzeczywistniać się miał „projekt zbiorowości ściśle powiatowej, a zarazem bezbrzeżnej, uniwersalnej, sięgającej w zaświaty i w wieczność"'.

Mimo zarazem politycznego i bluźnierczego gestu, jaki wykonał Kolankiewicz, struktura rozumienia świata, jego interpretacji w planie mitycznym i mistycznym pozostała w narracji o polskiej pamięci i kulturze nienaruszona - wciąż wpisana w porządek wertykalny i uniwersalny, nadający wszelkim wydarzeniom rangę elementu większej całości. Widać to wyraźnie zwłaszcza w ujęciu ciała, które ukazane zostało przez antropologa teatru jako medium pośredniczące między tożsamością własną a ,ja” odrębnym i ,autentycznym",

1 L. Kolankiewicz Dziady. Teatr święta zmarłych, słowo/obraz terytoria, Gdańsk 1999, s. 343. 
jako miejsce objawienia ducha, aktualizacji mitu, nie historii. W projekcie Kolankiewicza mamy zatem do czynienia ze światem trwałym, odradzającym się w oderwaniu od realnego doświadczenia politycznego i historycznego lub doświadczenie to na powrót obiektywizującym i uniwersalizującym. Jeśli pojawia się kryzys, zostaje wpisany w procesualną strukturę rytuału, a tym samym okazuje się możliwym do przezwyciężenia etapem, a nie momentem świadczącym o zmienności historii. W efekcie to, co potencjalnie odzyskane - lokalność, peryferyjność - zostaje ponownie utracone przez wyabstrahowanie doświadczenia ciała z jego specyficznych społecznych kontekstów i uwarunkowań.

Romantycznej kulturze odprawiania rytuałów żałoby, wertykalnej interpretacji wspólnoty, wreszcie wyłączaniu doświadczenia polskości z doświadczeń historycznych XX wieku skutecznie przeciwstawił się w swojej książce Grzegorz Niziołek, czyniąc wydarzenie Zagłady katalizatorem pisania o nowoczesności i teatrze polskim. Dzięki odejściu od „optymizmu antropologii” na rzecz uhistorycznienia polskiej pamięci oraz uruchomieniu narzędzi psychoanalitycznych autorowi Polskiego teatru Zagłady udało się zaproponować koncepcję teatru jako specyficznej maszyny pamięci. Ukazał bowiem polski teatr powojenny jako niewidziane dotąd pole „performowania niepamięci"2 o Szoa: nie tyle jako miejsce reprezentacji wypartych zdarzeń, ile raczej jako miejsce powtórzenia samego faktu wyparcia. Uważnie przyglądając się polskiej kulturze powojennej, a detalicznie jej teatralnym przejawom ${ }^{3}$, Niziołek odsłonił w swej pionierskiej książce świadome mechanizmy ideologicznej manipulacji historią i nieświadome mechanizmy stopniowego wypierania pozycji świadka Zagłady oraz strategie zaszyfrowywania aktu składania świadectwa. Takie ujęcie, skupione na kategorii widzenia, pozwoliło autorowi sformułować tezę o polskim społeczeństwie jak również o polskim teatrze powojennym jako o teatrze gapiów, bystanderów, postronnych i pasywnych obserwatorów cudzego cierpienia.

Tworząc swój traktat moralno-filozoficzny o złym widzeniu Zagłady, o dystrybucji i reglamentacji pola widzialności przez polskie społeczeństwo,

2 G. Niziołek Polski teatr Zagłady, Instytut Teatralny im. Zbigniewa Raszewskiego, Wydawnictwo Krytyki Politycznej, Warszawa 2013, s. 49.

Od przedstawień Leona Schillera, Aleksandra Bardiniego, Jana Świderskiego, przez spektakle Erwina Axera, Jerzego Grotowskiego, Tadeusza Kantora, Kazimierza Dejmka, Konrada Swinarskiego, Andrzeja Wajdy, po Jerzego Grzegorzewskiego, Krystiana Lupę, Krzysztofa Warlikowskiego i Ondreja Spišáka. 
Niziołek badał polski teatr powojenny w jego aspekcie wspólnotowym oraz jako sztukę wielokrotnie zapośredniczoną, immanentnie niejako skłonną do zniekształceń, przemieszczeń, kondensacji. To wspólnota doświadczająca konkretnych dzieł scenicznych stała się w Polskim teatrze Zagłady zbiorowym podmiotem i ciałem teatru, w którym zachodzą mechanizmy wyparcia i stłumienia i w którym szczególnie interesujące stają się powtarzające się zakłócenia, ponieważ dzięki nim to, co symptomatyczne, ujawnia się jako paradygmatyczne. Przesuwając punkt ciężkości na emocje i energię zbiorowości, Niziołkowi udało się wprawdzie rozkruszyć romantyczny model kultury oparty na micie polskiej ofiary, skłonności do „rytualizowania doświadczeń historycznych i podtrzymywania iluzji oczyszczających rytuałów”", niemniej w polu zainteresowania badacza teatru wciąż pozostała niezróżnicowana w istocie „polska zbiorowość”. I choć Niziołek w swej analizie przedstawień wielokrotnie eksponował cielesność jako ważny obszar badawczy, to jednak za każdym razem odwoływał się do jej wymiaru wspólnotowego, interpretując cielesność jako rodzaj energii zbiorowej, krążącej między sceną a widownią, jako efekt relacji między wizualnością i afektywnością. Z tego punktu widzenia ciało jednostkowe, wraz z jego uwarunkowaniami klasowymi, rasowymi czy genderowymi, okazało się zbyt partykularne, by mogło posłużyć autorowi Polskiego teatru Zagłady za przedmiot detalicznej refleksji i analizy.

W obu przywołanych tutaj modelach pamięci o polskim teatrze (a zarazem polskiej kulturze) - ze względu na prymat perspektywy doświadczenia wspólnoty - dochodzi z jednej strony do rytualizacji ciała jednostki (ciało jako miejsce aktualizacji mitu), z drugiej zaś do jego warunkowanego przynależnością do narodu zróżnicowania (ciało polskie versus ciało żydowskie). Swoista rywalizacja tych wielkich narracji o polskim teatrze nowoczesnym prowadzi jednocześnie do przesłaniania tych doświadczeń historycznych, które wiążą się z innymi - zarówno represyjnymi, jak i emancypacyjnymi - projektami nowoczesności. Za takie doświadczenie, które nie mieści się ani w paradygmacie uniwersalizującym polską peryferyjność, ani w modelu opartym na ustanowieniu równoległości między nowoczesnością a Zagładą, uznaję doświadczenie I wojny światowej w polskiej pamięci kulturowej. Wielką Wojnę traktuję nie tylko jako wydarzenie fundacyjne dla tożsamości europejskiej, ale również jako moment przełomowy dla spraw związanych z problematyką polskiej nowoczesności. Odnajdując, a zarazem konstruując

4 Tamże, s. 66. 
„inne źródło” polskiej nowoczesności w doświadczeniu Wielkiej Wojny, krytycznie analizuję zarówno interpretację polskiego modernizmu jako wyrazu ciągłości XIX-wiecznej kultury polskiej, jak również przyglądam się mechanizmom wypierania i przesłaniania obrazu krwawych, często bratobójczych walk z lat 1914-1918 przez procesy rytualnego upamiętniania wielomilionowych ofiar cywilnych z II wojny światowej.

Mój horyzont badawczy wyznacza negocjowanie znaczeń między przywołanymi tu modelami pamięci w polskiej historiozofii teatralnej a współczesnymi teoriami dotyczącymi performatywności archiwów. Te ostatnie uwypuklają bowiem interesującą mnie kwestię marginalizacji doświadczenia ciała jednostkowego, która wynika $\mathrm{z}$ faktu przypisywania ciału cechy efemeryczności jako uniemożliwiającej wszelki rodzaj zapisu, utrwalenia, zachowania ${ }^{5}$. W ten sposób ciało - jako rzekomo niepozostawiające trwałych śladów - zostało usunięte $\mathrm{z}$ archiwum, a tym samym z pola oddziaływania na narrację historyczną i politykę tożsamościową. Odwołując się głównie do metodologii wypracowanej na gruncie współczesnych badań archiwalnych i performance studies, proponuję przyjrzenie się performatywnym strategiom oraz praktykom zachowywania i ocalania, a także wypierania i zapominania wydarzeń z lat 1914-1918 w polskiej pamięci kulturowej. Czynię to na podstawie starannie wyselekcjonowanego materiału archiwalnego, dokumentującego rozmaite sposoby manifestowania się fundamentalnego dla „teatru Wielkiej Wojny” medium - ciała żołnierza I wojny światowej.

Badając pamięć kulturową, proponuję zatem wyprowadzone z praktyki teatralnej ujęcie historii, które wydobywa jej wymiar archiwalny, czyli zachowujący, utrwalający wydarzenie, oraz performatywny, czyli znikający,

5 W ustanowieniu na nowo relacji między ciałem/cielesnością a pamięcią/pamiętaniem oraz archiwum/archiwizowaniem rolę moich przewodników odgrywają współcześni, w przeważającej mierze amerykańscy teoretycy i teoretyczki performansu, tacy jak Peggy Phelan, José Esteban Muñoz, Rebecca Schneider czy Diana Taylor. To ci badacze, wychodząc z rozmaitych pozycji - uznania mortyfikującego wpływu obrazu na działanie (Phelan), nienormatywnej obecności i reprezentacji ciała (Muñoz), transmisji doświadczeń z ciała do ciała w praktykach rekonstrukcyjnych (Schneider), związków między repertuarem zachowań a archiwum (Taylor) - doszli do podobnych rozpoznań. Zob. P. Phelan Unmarked: The Politics of Performance, Routledge, New York 1993; J.E. Muñoz Ephemera as Evidence: Introductory Notes to Queer Acts, "Women and Performance. Journal of Feminist Theory" 1996 no. 8(2), s. 5-16; R. Schneider Performing Remains: Art and War in Times of Theatrical Reenactment, Routledge, New York 2011; D. Taylor The Archive and the Repertoire. Performing Cultural Memory in the Americas, Duke University Press, Durham-London 2003. 
rozpraszający się w czasie i przestrzeni. Teatr traktuję jako swoiste archiwum kultury oraz jako szczególny sposób manifestowania się i jednoczesnego komentowania własnej kultury, polityki i historii. Jednocześnie ukazuję go jako sztukę immanentnie skażoną śmiercią, anachroniczną i „spóźnioną" wobec awangardowych praktyk artystycznych i pasożytującą na resztkach innych mediów - fotografii, filmu, literatury, muzyki. Moja perspektywa wyrasta z przekonania, że leżąca u podstaw teatrologii jako nauki nowoczesnej sprzeczność między archiwum a performansem (dokumentacją a działaniem) jest pozorna, stanowi bowiem pewien mit kulturowy, wynikający z logiki tradycyjnie rozumianego archiwum jako magazynu trwałej materii, a zarazem trwałych sensów i wartości. Logiki często odrzucającej inne sposoby poznania, inne sposoby pamiętania, które z kolei oferuje w moim ujęciu praktyka performatywna - czyniąca z nieustannie zagrożonego zniknięciem (śmiercią) ciała swoiste archiwum historii oraz pamięci indywidualnej i kolektywnej.

W swojej refleksji na temat ciała jako dokumentu historii kultury - negocjując znaczenia między myślą antropologiczną i teatrologiczną, a także uwzględniając genealogię tych dyscyplin jako par excellence nowoczesnych - proponuję perspektywę badawczą skoncentrowaną wokół epistemologicznego, medialnego, a zarazem historycznego i politycznego wymiaru cielesności. Moim zamiarem jest próba wyznaczenia innego spojrzenia na związki teatru i śmierci niż z miejsca zajmowanego przez (uniwersalny) podmiot powtarzający mit, odprawiający rytuał i/lub tworzący narracje, lecz fragmentaryczna rekonstrukcja z punktu widzenia podmiotów krytycznie analizujących własne uwikłanie w te historycznie zmienne kategorie. W przeciwieństwie do przywołanych tu obu modeli pamięci teatru polskiego, bazujących na paradygmacie świadectwa, a przez to ukazujących teatr zawsze z perspektywy doświadczenia, moja koncepcja oparta jest na paradygmacie dowodu - resztki, śladu, pozostałości, dla którego kluczową kategorią nie jest doświadczenie, lecz właśnie rekonstrukcja. W tym celu proponuję dwa pozostające ze sobą w głębokiej korelacji pojęcia: c i ało-a r chiw u m oraz nekroperformans jako kategorie problematyzujące również stosunek badacza do materii archiwalnej, określające jednocześnie konkretną strategię i praktykę pisania historii kultury.

Ciało-archiwum to traktowana przeze mnie jako agens wszelka materialna dokumentacja przeszłości: kości, szczątki organiczne, przedmioty i miejsca, a także poddane medialnej archiwizacji i technologicznej reprodukcji resztki przeszłości, zachowane w świadectwach żyjących „tam i wtedy” oraz 
zarówno w ówczesnych, jak i we współczesnych dziełach tekstowych, audialnych, wizualnych i teatralnych. Ciało-archiwum to nie tylko dająca się bezpośrednio doświadczyć materia archiwalna znajdująca się w specjalnie do tego przeznaczonej instytucji, zajmującej się gromadzeniem i klasyfikacją zbiorów. To również wszelkie ożywiane w performansach społecznych i artystycznych za pomocą rozmaitych mediów resztki historii oraz krążące w wolnym i fragmentarycznym obiegu internetu poddane cyfrowym procesom archiwizacji dane źródłowe. Pozostałości historii, traktowane jako żywa materia, nie ograniczają się zatem do bezpośrednio namacalnej obecności i aktywności rzeczy. Równie ważna jest remediacja materii, ponieważ dopiero wielokrotne zapośredniczenia ujawniają zachodzące pod wpływem sposobów dokumentowania, przechowywania i używania archiwaliów procesy transsubstancjacji. Te „inne” archiwa - przestrzeń społeczna, sztuka i internet - zachowują zatem pamięć o „właściwej” przestrzeni archiwum jako domu Archonta (Jacques Derrida), pozwalając na krytyczne ujęcia samych procesów archiwizacji.

Nekroperformans stanowi z kolei narzędzie pozwalające na uchwycenie w kulturze momentów mediacji, transmisji i transformacji materialnych pozostałości historii. Nekroperformans jest pojęciem teoretyczno-analitycznym, dzięki któremu ujawnia się dynamika, procesualność i zwrotność relacji między badającym a badanym. Ponieważ teoria materializuje się tutaj pod wpływem uruchomienia materiału historycznego, a zatem ożywienia przez badacza w „tu i teraz" świadomie wybranych, ponownie odzyskanych lub przypadkowo odkrytych pozostałości historii, konieczna jest praca na konkretnej materii archiwum. Dopiero w procesie analizy dokumentacji, poddanym regułom kontekstualizacji, historyzmu i komparatyzmu ${ }^{6}$, może odsłonić się sieć powiązań między praktykami emancypacyjnymi a zabiegami puryfikacyjnymi nowoczesności. Dzięki temu nekroperformans może stać się skutecznym narzędziem tego, co Bruno Latour nazywa antropologia nowoczesnych? , która zamiast wytwarzać Innego - jak czyniły to dwa kluczowe dyskursy nowoczesności: antropologia i psychoanaliza - bada Tego Samego w jego historycznej zmienności.

6 Zob. E. Traverso Historia jako pole bitwy. Interpretacja przemocy wXX wieku, przeł. Ś.F. Nowicki, Książka i Prasa, Warszawa 2014, s. 24.

7 Zob. B. Latour An Inquiry into Modes of Existence, przeł. C. Porter, Harvard University Press, Cambridge 2013. 
Podejmując próbę sformułowania innego modelu pamiętania w kulturze polskiej na podstawie polskiego doświadczenia Wielkiej Wojny, proponuję wyprawę etnograficzną do archiwum teatralnego w celu podjęcia eksperymentu badawczego. Moim celem jest próba odpowiedzi na pytanie, na ile umieszczenie u źródeł polskiej nowoczesności prapremierowego wystawienia Powrotu Odysa Stanisława Wyspiańskiego, które odbyło się 24 listopada 1917 roku, pozwoli na artykulację doświadczenia historycznego niemieszczącego się w rozpoznawalnych przez polską pamięć scenariuszach życia społecznego i politycznego. Casus Stanisława Wyspiańskiego jako artysty, który stał się - by tak rzecz - ofiarą polskiej pamięci po 1918 roku, wydaje się tu szczególnie ciekawy. Jeszcze w trakcie Wielkiej Wojny poeta został bowiem wpisany w oddziaływanie legendy Józefa Piłsudskiego, o którym mawiano, że miał tylko wykonywać „wszystko to, co pierwszy wyobraźnią narodowego artysty «zaprogramował» w literackich i teatralnych wizjach"8. Proces interpretacji twórczości Wyspiańskiego jako postromantycznej dramaturgii narodowej, opartej na powtarzaniu XIX-wiecznej symboliki śmierci i zmartwychwstania, przekształcił się w Polsce niepodległej w mechaniczny rytuał utrwalający pamięć o Wielkiej Wojnie jako o czynie powstańczym i legionowym. Ten odwołujący się do resentymentu performans pamięci doprowadził niewątpliwie do zideologizowania, a zarazem brzemiennego w skutkach zwulgaryzowania teatralnej i filozoficznej wizji Stanisława Wyspiańskiego, co w latach 30. celnie zauważył Manfred Kridl, pisząc,

że twórczość Wyspiańskiego niszczy „skrót prosty, przystępny i łatwy do zapamiętania". Banalizuje on i fałszuje indywidualność pisarza, przykrywając ideologicznie jego dzieła, przekreślając artystyczną całość jego dorobku, przystosowując go generalnej miałkości popularnych ujęć patriotycznych tematów, dla których okazuje się patronem. ${ }^{9}$

W tej perspektywie prapremiera Powrotu Odysa z 24 listopada 1917 roku w inscenizacji i z główną rolą Józefa Sosnowskiego wydaje się wypartą pozostałością nieopowiedzianej dotąd historii, śladem pozwalającym na skonstruowanie innej niż powszechnie znana wersja przeszłości.

8 W. Wójcik Legenda Piłsudskiego w polskiej literaturze międzywojennej, Wydawnictwo "Śląsk", Katowice 1986, s. 40.

9 D. Ratajczakowa Obrazy narodowe w dramacie i teatrze, Wydawnictwo Wiedza o Kulturze, Wrocław 1994, S. 329. 
W zbiorach Archiwum Artystycznego i Biblioteki Teatru im. Słowackiego w Krakowie znajduje się dość różnorodny zestaw materiałów archiwalnych, dokumentujących pierwszowojenną inscenizację dramatu Wyspiańskiego. Egzemplarz reżyserski sztuki wraz z obsadą i nielicznymi skreśleniami ołówkiem, szkice sytuacyjne scenografii ze wszystkich trzech aktów, niepełna partytura muzyczna autorstwa Zdzisława Jachimeckiego, pojedyncze wycinki prasowe, afisze oraz sześć fotografii wykonanych przez aktora i reżysera tego teatru, przy tym znakomitego fotografa amatora Wacława Szymborskiego tworzą korpus materialnych śladów przedstawienia. I to owe materialne resztki pozwalają dziś na konstruowanie pamięci o Powrocie Odysa jako o wydarzeniu teatralnym, odbywającym się w Krakowie dokładnie w tym samym roku, kiedy polski poeta, a zarazem żołnierz armii austriackiej Józef Wittlin, przebywający we włoskim obozie jenieckim, rozpoczął pracę nad przekładem Odysei $i^{10}$.

W tym układzie fragmentarycznie i przypadkowo w istocie zachowanych dokumentów, potwierdzających tradycyjne przekonanie o Powrocie Odysa Wyspiańskiego jako o sztuce dokonującej modernistycznego przepisania znanego motywu antycznego, jedno zdjęcie zwraca dzisiaj szczególną uwagę. Fotografia ta ukazuje „skalne pustkowie nad morzem" z aktu III sztuki, zaprojektowane przez Zbigniewa Pronaszkę jako skaliste nabrzeże z rozsypanymi wokół ludzkimi piszczelami i czaszkami. Dekoracja ta trafnie oddaje stan psychofizyczny protagonisty dramatu, który po dokonaniu serii morderstw-powtórzeń ostatecznie rozpozna własny dom i własną ojczyznę jako cmentarz, na którym „ścierwem cuchnie”, a znajdujące się wokół „szcząty - ludzkie kości. - "11 jako ostateczną realność, której stał się zarówno świadkiem, jak i powodem: „Żyję; zabiłem wszystko - wszystko odepchnąłem; [...] / Nic, nic poza mną; - nic - nic - nic przede mną"12. Uchwycona przez Wacława Szymborskiego przestrzeń śmierci zderzona została z ostentacyjną teatralnością

Pierwsza wersja tłumaczenia, ta wyrosła z ducha epoki i pozostająca (do czego przyznawał się sam autor) pod silnym wpływem języka Stanisława Wyspiańskiego, ukazała się drukiem w 1924 roku. Wittlin przez wiele lat poddawał rewizji przekład Odysei. W rezultacie powstały trzy ogłoszone drukiem wersje: z 1924 roku, 1931 roku i 1957 roku. Zob. J. Korpanty Zapomniany tłumacz "Odysei" Homerowej, „Przekładaniec” 2007 nr 18-19, s. 193, http://www.ejournals.eu/Przekladaniec/2007/Numer-18-19/art/3099/ (12.01.2015). Zob. także Homer Odyseja, przeł. J. Wittlin, Świat Książki, Warszawa 1999.

S. Wyspiański Powrót Odysa, w: tegoż Achilleis, Powrót Odysa, oprac. J. Nowakowski, Zakład Narodowy im. Ossolińskich, Wrocław 1984, s. 283.

12 Tamże. 
postaci Syren z jednej strony, z drugiej zaś z martwotą nieruchomego morza ${ }^{13}$, z którego Odys - odziany w łachmany, zarośnięty żebrak - wydobywa swoje ciało na brzeg. I to dzięki tej właśnie fotografii - wizualnej resztce przedstawienia teatralnego - możemy dziś patrzeć na swoistą konstelację teatru, ciała, kości i wojny.

Konstelacja to niewątpliwie szczególna, zachęcająca do szerszej historycznokulturowej interpretacji. Itaka z rozsypanymi wokół suchymi kośćmi ludzkimi jest jakby scenicznym echem wizji Ezechiela, ukazującej dolinę wysuszonych kości zmienioną w pobojowisko na skutek wielkiego pogromu. Zamykający spektakl obraz mógłby być zatem próbą zbudowania paraleli między niewolą i wygnaniem Izraelitów a sytuacją narodu polskiego, a zarazem wzbudzenia nadziei na rychłe odrodzenie. Dzięki interwencji proroka naród, który sprawiał wrażenie martwego, otrzymuje przecież nowe życie: najpierw kości zbliżają się do siebie, potem pojawiają się ścięgna, narasta ciało i wszystko okrywa się skórą. Wreszcie na słowa proroka w martwe ciała ludzkie wstępuje Bóg, a wówczas ożywają i tworzą wielkie wojsko ${ }^{14}$. Jednak w przedstawieniu Józefa Sosnowskiego - choć w 1917 roku szansa na niepodległość Polski wydawała się coraz bardziej realna - nie dochodzi do ożywienia kości. Nie realizuje się też wzorzec z mocno zakorzenionej w polskiej pamięci kulturowej legendy o św. Stanisławie, którego „porozrywane i poszarpane mieczem przemocy szczątki cielesne" samoistnie (choć za sprawą ptaków niebieskich) zrosły się ponownie w jednolitą całość. „Szcząty ludzkie” w Powrocie Odysa pozostają na scenie do końca, wytrwale, w funkcji martwego

13 Fakt unieruchomienia morza krytykował np. Władysław Prokesch. Zob. W.Pr. Powrót Odysa, "Nowa Reforma" nr 546 z 26 listopada 1917, wydanie poranne.

14 W Księdze Ezechiela (37, 1-10) czytamy: 1 Potem spoczęła na mnie ręka Pana i wyprowadził mnie On w duchu na zewnątrz, i postawił mnie pośród doliny. Była ona pełna kości. / 2 I polecił mi, abym przeszedł dokoła nich, i oto było ich na obszarze doliny bardzo wiele. Były one zupełnie wyschłe. / 3 I rzekł do mnie: „Synu człowieczy, czy kości te powrócą znowu do życia?”. Odpowiedziałem: „Panie Boże, Ty to wiesz". / 4 Wtedy rzekłOn do mnie: „Prorokuj nad tymi kośćmi i mów do nich: Wyschłe kości, słuchajcie słowa Pana!". / 5 Tak mówi Pan Bóg: Oto Ja wam daję ducha po to, abyście się stały żywe. / 6 Chcę was otoczyć ścięgnami i sprawić, byście obrosły ciałem, i przybrać was w skórę, i dać wam ducha po to, abyście ożyły i poznały, że Ja jestem Pan". / 7 I prorokowałem, jak mi było polecone, a gdym prorokował, oto powstał szum i trzask, i kości jedna po drugiej zbliżały się do siebie. / 8 I patrzyłem, a oto powróciły ścięgna i wyrosło ciało, a skóra pokryła je z wierzchu, ale jeszcze nie było w nich ducha. / 9 I powiedział On do mnie: „Prorokuj do ducha, prorokuj, o synu człowieczy, i mów do ducha: Tak powiada Pan Bóg: Z czterech wiatrów przybądź, duchu, i powiej po tych pobitych, aby ożyli". / 10 Wtedy prorokowałem tak, jak mi nakazał, i duch wstąpił w nich, a ożyli i stanęli na nogach - wojsko bardzo, bardzo wielkie. 
przedmiotu, są - tak jak prawda u Brechta - konkretne. Wskazują wyłącznie na przyczynę pobojowiska - przemoc.

Zdjęcia z krakowskiego Powrotu Odysa sąsiadowały w ówczesnych gazetach z fotografiami przedstawiającymi rzadziej oddziały Legionów, a częściej zgliszcza Europy. W numerze 50 „Nowości Ilustrowanych” z 1917 roku oprócz zdjęć i recenzji z Powrotu Odysa pojawiły się doniesienia Z frontów bojowych oraz wiele fotografii przedstawiających kolejno: ruiny włoskiego Conegliano po zajęciu przez armie sprzymierzone, uszkodzoną pociskami artylerii więżę kościoła w Ponte di Piave, resztki kościoła w Gheluvelt zburzonego przez Anglików, zniszczony przez Włochów most kolejowy na rzece Tagliamento, szczątki zestrzelonego samolotu. Zdjęcie ukazujące próbę napięcia łuku Odysowego raczej nieprzypadkowo znalazło się na jednej stronie ze zdjęciem żołnierza prezentującego bombę powietrzną. Fotografia Szymborskiego przedstawiająca skalne nabrzeże z ludzkimi kośćmi ma w tym układzie wizualnym, ukazującym ruiny Europy jako pozostałości po człowieku, nie tylko charakter aktualny i publicystyczny, ale również antropologiczny. Jednocześnie odsłania nieobecny w polskiej refleksji historycznokulturowej związek antropologii i teatru, który wywraca na nice romantyczne wyobrażenia o śmierci i związanych z nią obrzędach, polegających na wywoływaniu duchów zmarłych. Ta konstelacja - jakże materialna, wystawiająca na pokaz fragmentaryczność i skandaliczność śmierci - ukazuje bowiem podmiotowość fundowaną na kościach, trupach i realnej przemocy, a nie na duchach przodków.

Tak rozumiane źródła podmiotowości stanowiły wprawdzie zasadnicze doświadczenie Polaków przez cały wiek XIX, jednak w narracji o polskiej śmierci - heroicznej, a zarazem opartej na ofierze i odwołującej się do porządku wertykalnego - zostały skutecznie wyparte. Ogromną rolę w tym procesie mito- i wspólnototwórczym odegrała polska literatura romantyczna, te - jak mawiał Żeromski - utwory plemienne, ten „cement spajający rozerwane części narodu", który nie pozwalał uwolnić się od brzemienia minionych zdarzeń na rzecz politycznie lepiej zorganizowanego narodu i społeczeństwa przyszłości. Stanisław Wyspiański już w Wyzwoleniu walczył z widowiskiem polskości, egzorcyzmującym duchy i widma przeszłości, uniemożliwiające doświadczanie (także politycznego) tu i teraz. W Legionie, podejmując historiozoficzną dyskusję z ideologią polskich powstań narodowych, Wyspiański wskazywał natomiast na właściwe polskiej tożsamości pielęgnowanie trupów braci i ojców - „chlustających krwi szkarłatem”, „żrejących się wzajem, szarpiących i mordujących”. We wciąż ożywających 
- a właściwie nieustannie reanimowanych przez dyskurs narodowowyzwoleńczy - martwych pozostałościach odwoływał się do specyficznie polskiego imaginarium społecznego, bazującego na literackim archiwum szczątków przodków. I choć motyw ossa - kości ludzi zmarłych - obecny był już w literaturze staropolskiej ${ }^{15}$, to jednak dopiero wiek XIX związał ten prastary topos z doświadczeniem przeżywanej w warunkach zależności od obcych imperiów polskiej nowoczesności: począwszy od Mickiewiczowskiego Pana Tadeusza, gdzie weteran spod San Domingo przynosił „kości stare na ziemię ojczystą, / Której już bronić nie mógł...", aż po Legion Wyspiańskiego, w którym wędrowny śpiewak Rapsod opiewał w swych pieśniach narodowych odradzające się trupy polskich żołnierzy: „Strzępy, strzępy; / ożarły się syto sępy / i tej krwi, i tej odzieży, / w błocie, w brudzie serce leży / i grób świeży, i trup świeży, - / duch się plącze"16.

W Powrocie Odysa Wyspiański ostatecznie porzucił dyskusję z narodowym archiwum szczątków, by głębiej wniknąć w istotę problemów współczesnych mu społeczeństw europejskich. W dramacie pisanym w okresie gorzkich rozczarowań Rewolucją w Królestwie poeta odkrył anachroniczność narodowej, odwołującej się do resentymentu powstańczego, koncepcji wspólnoty. Wspólnoty, o której w tym samym czasie zaangażowana w rewolucję Róża Luksemburg pisała jako o relikcie Polski szlacheckiej i przedkapitalistycznej. W artykułach z 1905 roku, poświęconych kwestii polskiej i ruchowi socjalistycznemu, Luksemburg określała poglądy Marksa i Engelsa, którzy widzieli w polskich powstaniach narodowych istotny czynnik rewolucyjny prowadzący do idei wypowiedzenia wojny Rosji,jako „przeżytki

15 W Słowniku staropolskim czytamy np. „Bog rosypa cosczi gich (ossa eorum)”, "Gednegonasczye dnya vstaną s martvych kosczy vmarlych (ossa mortuorum)" (Słownik staropolski, t. 3, z. 5 (18), Zakład Narodowy im. Ossolińskich Wydawnictwo Polskiej Akademii Nauk, Wrocław-Warszawa-Kraków 1962, s. 363). Słownik polszczyzny XVI wieku podaje zaś takie związki frazeologiczne, jak „kościom się modlić”, „kości opłakiwać”, „kości przenaszać”, „kości wenerować”, „oddać kości ziemi" (Słownik polszczyzny XVI wieku, t. 11, Zakład Narodowy im. Ossolińskich Wydawnictwo Polskiej Akademii Nauk, Wrocław 1978, s. 71-73). W Pamiętnikach Paska (pod datą Rok Pański 1676) widnieje natomiast taki zapis: „Do Krakowa przywieziono króla ciało, Michała; przywieziono też i Kazimierza ze Francyjej, choć z nami nie chciał życia swego kończyć, a po staremu po śmierci do nas przyjechał. [...] wzgardziłeś dobrowolnie ojczyzną, która cię wychowała i dotrzymowała zawsze miłości i wiary, a kości twoje pragnęły, żeby się do niej powróciły i w niej spróchniały!" (J.Ch. Pasek Pamiętniki, wstęp i objaśnienia W. Czapliński, Zakład Narodowy im. Ossolińskich, Wrocław 1979, s. 501).

16 S. Wyspiański Legion, w: tegoż, Dzieła zebrane, t. 3, red. zespołowa pod kier. L. Płoszewskiego, Wydawnictwo Literackie, Kraków 1958, s. 183. 
dawnych pojęć, oparte na nieznajomości społecznej treści ruchów narodowych wewnątrz Polski, jak i zmian społecznych, zaszłych w Polsce od czasu ostatniego powstania"17. Uważała, że peryferyjna Polska po powstaniu styczniowym pod wpływem kapitalizmu przekształca się w kraj nowoczesny, którego motorem staje się walka klas, ten proces transformacji formułowała zaś jako ideę tańca modernizmu na szczątkach anachronicznej przeszłości.

W rzeczywistości „die Polen”, to jest ów naród niezróżniczkowany "polaków”, których jedynym rzemiosłem była rzekomo walka o niepodległość, jeśli kiedykolwiek istniał, to w chwili, gdy Engels słowa te pisał, w każdym razie dawno istnieć przestał. Była to bowiem u nas właśnie chwila największych orgji „pracy organicznej”, rozpoczynał się szalony tan kapitalistycznej gospodarki i kapitalistycznego zbogacania się - na grobie narodowych ruchów i szlacheckiej fazy w życiu Polski. ${ }^{18}$

Wyspiański nie sformułował, rzecz jasna, w swym ostatnim tekście teatralnym tak jawnych wniosków politycznych, lecz niewątpliwie głęboko zdystansował się wobec starannie selekcjonowanych przez polską pamięć szczątków służących odnawianiu idei wspólnoty narodowej. Być może mając świadomość innych zbrodni, jakie społeczeństwa europejskie dokonywały na początku XX wieku w Afryce, przeciwstawiał się również „pamięci narodu skolonizowanego", za jaki uważali (i nadal uważają) się Polacy, kodując w języku poezji niejednoznaczną relację między sprawcą a ofiarą. Uchwycona przez Wyspiańskiego w śródziemnomorskim micie o Odyseuszu idea człowieka pozbawionego ojczyzny, który nie może powrócić do domu i którego jedynymi śladami istnienia są wciąż na nowo gromadzące się „,szcząty ludzkie", niewątpliwie przyniosła odmienny rodzaj myślenia o uchodźctwie niż ten, który dominował w micie romantycznym, utożsamiającym tułacza-pielgrzyma z Polakiem. Ten radykalny politycznie obraz musiał jednak czekać na swoją materializację sceniczną aż do momentu całkowitego załamania

17 R. Luksemburg Przedmowa, w: Kwestja polska a ruch socjalistyczny. Zbiórartykułów o kwestji polskiej R. Luksemburg, K. Kautsky'ego, F. Mehringa, Parvusa i innych, z przedmowq R. Luksemburg, z uwagami wydawców oraz dodatkiem, Socjaldemokracja Królestwa Polskiego i Litwy, Kraków 1905 , s. V.

18 Tamże. 
podstaw politycznych, społecznych i ekonomicznych starego porządku europejskiego - do listopada 1917 roku.

Wydaje się symptomatyczne, że spośród wielu sprawdzonych w teatrze sztuk, które zapewniły Wyspiańskiemu jeszcze za życia tytuł wieszcza narodowego, akurat dramat o żołnierzu mordercy i wygnańcu wybrany został na uczczenie dziesiątej rocznicy śmierci autora ${ }^{19}$. Co więcej, decyzja o wystawieniu tej skrajnie pesymistycznej sztuki zapadła w Krakowie, gdzie 3 sierpnia 1914 roku z inicjatywy Józefa Piłsudskiego w pełnej euforii powołano do życia Pierwszą Kompanię Kadrową i gdzie jeszcze 5 listopada 1916 roku z wiarą przyjęto akt cesarzy Austro-Węgier i Niemiec zapowiadający utworzenie państwa polskiego. Objawy masowej czci wobec Piłsudskiego dały się zaobserwować również w Teatrze im. Słowackiego, w którym w listopadzie 1916 roku przez tydzień grano specjalnie dla wodza Legionów uroczyste przedstawienia Ślubów panieńskich i Kościuszki pod Racławicami. Patriotyczne obchody w teatrze, w którym zasiadło wówczas wielu umundurowanych widzów, przerywane były powstawaniem z miejsc, odśpiewaniem pieśni Boże, coś Polskę i wysłuchaniem w skupieniu Mazurka Dąbrowskiego, a także płaczem, oklaskami i okrzykami „Niech żyje Piłsudski!”20, co uczyniło z Komendanta właściwego protagonistę obu przedstawień. Coś szczególnego musiało się zatem wydarzyć w dramacie społecznym, skoro kilkanaście miesięcy później na tę samą scenę powrócił bohater starożytnego eposu, który został przedstawiony nie jako synonim polskiego żołnierza, lecz jako obraz kondycji ludzkiej warunkowanej przedłużającą się w nieskończoność, wykańczającą psychofizycznie Wielką Wojną Nowoczesności.

W książce Nacht über Europa. Kulturgeschichte des Ersten Weltkrieges („Noc nad Europą. Kulturowa historia I wojny światowej”) niemiecki historyk Ernst Piper wskazuje na drastyczną cezurę, jaka nastąpiła po krwawym roku 1916, który przyniósł największą liczbę umarłych, rannych i uwięzionych. Z tej perspektywy rok 1917 jawi się nie tyle jako okres zabójczej walki, ile jako czas żołnierzy znajdujących się na skraju wyczerpania fizycznego i psychicznego.

19 W Warszawie śmierć Wyspiańskiego upamiętniono, zgodnie ze zwyczajem umieszczania poety $w$ tradycji niepodległościowej, fragmentami Legionu i Lelewela, które zostały pokazane 28 listopada 1917 roku w Teatrze Polskim z legendarnym Ludwikiem Solskim w roli Mickiewicza i Lelewela. Ludwik Solski był również reżyserem tego przedstawienia. Zob. J. Got Zwycięski pochód, w: Wyspiański i teatr 1907-1957, [red. A. Woycicki], Teatr im. Słowackiego, Kraków 1957, s. 98.

20 Pisze o tym szczegółowo D. Poskuta-Włodek Trzy dekady z dziejów sceny. Teatr im. Juliusza Słowackiego w Krakowie 1914-1945, Teatr im. Juliusza Słowackiego, Kraków 2001, s. 89-90. 
Gigantyczny przyrost liczby kalek i inwalidów zaowocował niebywałym rozwojem medycyny ${ }^{21}$, zwłaszcza w zakresie rozpowszechnienia środków znieczulających i antyseptycznych, a przede wszystkim chirurgii kości, mózgu oraz chirurgii rekonstrukcyjnej. W 1917 roku - pod naciskami weterynarzy - znacząco poprawiła się również sytuacja zwerbowanych na wojnę zwierząt, wtedy bowiem „system zostaje zreorganizowany na wzór opieki medycznej dla ludzi”22. Był to zarazem czas, który przyniósł najmniej ofiar śmiertelnych, za to najwięcej głodu, rozczarowań i rezygnacji. „Rok 1917 to nie czas generałów, lecz lekarzy. Trauma wojenna została wówczas rozpoznana jako cierpienie psychiczne"23. Czyżby zatem w postaci Odysa - nie tyle powracającej na scenę teatru polskiego, ile raczej upiornie na niej obecnej - rozpoznać można kulturową figurę dotkniętego dezintegracją fizyczną i psychiczną żołnierza Wielkiej Wojny?

Warto spojrzeć na zmianę, która dokonała się na scenie Teatru im. Słowackiego z perspektywy zdiagnozowanego przez Pipera głębokiego kryzysu społecznego. Powszechne, ponadnarodowe doświadczenie porażki cywilizacyjnej, jaką okazała się wojna, musiało bowiem wpłynąć również na reprezentację tej rzeczywistości w teatrze polskim. Podczas gdy jeszcze w prapremierowym wystawieniu Akropolis Wyspiańskiego z 1 grudnia 1916 roku ówczesny dyrektor Adam Grzymała-Siedlecki w celu „wydobycia akcentów optymistycznych, istotnych dla rozbudzonych nadziei na rychłą niepodległość"24 usunął trzeci akt sztuki, co spotkało się z krytyką jedynie redaktora

21 Już w trakcie wojny istniała świadomość nieporównywalnego z żadną poprzednią wojną stanu medycyny. Ciekawy przykład edukowania żołnierzy i społeczeństwa w sprawie postępu medycyny stanowi książeczka wydana przez dra Konrada Biesalskiego, lekarza i dyrektora Oscar-Helene-Heim w Berlinie, Die Fürsorge für unsere heimkehrenden Krieger, insbesondere die Kriegskrüppelfürsorge, Verlag von Leopold Voss, Lepzig-Hamburg 1915. Autor przedstawia tutaj sposoby pomocy inwalidom wojennym - zarówno w aspekcie medycznym, jak ispołecznym.

É. Baratay Zwierzęcy punkt widzenia. Inna wersja historii, przeł. P. Tarasewicz, Wydawnictwo w Podwórku, Gdańsk 2014, s. 229. Baratay podaje też konkretne przejawy tej reorganizacji systemu sanitarnego dla zwierząt: „Konie z rekwizycji separuje się od chorych, które najpierw poddane zostają kwarantannie w specjalnych stajniach, gdzie dzieli się je na zakaźnie chore, podejrzane, wolne od chorób zagrażających innym, a następnie określa się ich przypadłość (wewnętrzna, skórna, pooperacyjna...), żeby mogły trafić w ręce bardziej wyspecjalizowanego personelu". Tamże, s. 230.

E. Piper Nacht überEuropa. Kulturgeschichte des Ersten Weltkriegs, Propyläen Verlag, Berlin 2013, s. 399 . 
socjalistycznego „Naprzodu” Emila Haeckera ${ }^{25}$, to już rok później Grzymała-Siedlecki poparł inscenizację Powrotu Odysa, tego „poetyckiego, ale niezwykle aktualnego komentarza do losów tysięcy rozsianych na wszystkich frontach Europy współczesnych «Odysów»"26.

Nie bez znaczenia były także przemiany, do jakich doszło wówczas w zespole aktorskim, a przede wszystkim w społecznej strukturze publiczności krakowskiej. Z jednej strony w 1917 roku nastąpiła największa w historii Teatru im. Słowackiego fala powrotów aktorów, zarówno z teatrów Wiednia i Warszawy (wśród nich był też Józef Sosnowski), jak również z pola bitwy - znaleźli się bowiem i tacy, którzy właśnie zostali zwolnieni z woj$\mathrm{ska}^{27}$. Z drugiej zaś strony na widowni zaczęła zasiadać nowa klasa ludzi, często niepochodzących z Galicji, uznawanych za „obcych”, którzy wzbogacili się dzięki wojennym interesom, przede wszystkim na handlu żywnością, a teraz przez uczestnictwo w kulturze dążyli do szybliego awansu ${ }^{28}$. Diana Poskuta-Włodek celnie nazwała okres dyrekcji Grzymały-Siedleckiego, kiedy to teatr rozumiany jako mikrokosmos społeczny podlegał nieznanym dotąd rekonfiguracjom, „teatrem dla Odysów”, uwypuklając tym samym związek między tożsamością nowoczesną a doświadczeniem wojny, która miała być triumfem kapitalizmu i imperializmu, a która - mnożąc zyski czerpane z przemocy i śmierci - okazała się przejawem upadku cywilizacji europejskiej.

W Powrocie Odysa, odwołującym się do nowoczesnych ruin mitu śródziemnomorskiego, a nie do romantycznego ujęcia polskiej historii jako miejsca manifestacji peryferyjnej wspólnoty „naszych umarłych”, udało się Wyspiańskiemu uchwycić realność, materialność, a zarazem powszechność śmierci oraz jej związek z konstytuowaniem się podmiotowości. Kości, tak starannie selekcjonowane w polskiej pamięci kulturowej, to u Wyspiańskiego po prostu „szcząty ludzkie”, które powracają na scenę historii, by ukazać nie tyle jej trwałość, ile właśnie zmienność. Można zatem powiedzieć, że Wyspiański, porzucając przekonanie o szczególnej randze mitu polskości i wyjątkowości partycypacji polskiej zbiorowości w historii, zaprojektował w miejsce

25 Zob. E. Haecker Z teatru. „Akropolis” Wyspiańskiego w skróceniu, "Naprzód” 1916 nr 334, cyt. za:

D. Poskuta-Włodek Trzy dekady z dziejów sceny..., s. 91. 
„Teatru święta zmarłych”29, dążącego do kompletności mitu i skuteczności rytuału - swoistą alternację teatru śmierci, odwołującego się wyłącznie do resztki, fragmentu, pozostałości. Zaproponował więc nowoczesną wersję teatru śmierci, który uniemożliwiając reintegrację wspólnoty polskich żywych i umarłych, nie tyle lokuje polskie doświadczenie śmierci gdzieś na wykluczonych z procesu zachodniej nowoczesności peryferiach Europy, ile raczej krytycznie umieszcza polskość wewnątrz kultury europejskiej, jej historii i polityki.

Ten rodzaj działania tego, co martwe, na to, co żywe, które prowadzi do rozsunięcia między doświadczeniem (Erfahrung), opierającym się na usankcjonowanej powtarzalności, a przeżyciem (Erlebnis), przybierającym formę traumatyzującego nadmiaru energii, nazywam nekroperformansem. Nekroperformans ujawnia bowiem odnalezioną przez Benjamina w doświadczeniu I wojny światowej rozłączność systemów percepcji i świadomości, a tym samym stanowi odmienny sposób manifestacji przeżycia niż reprezentacja w postaci tradycyjnych form zapisu i pamięci. Stanowi on sytuację, w której za sprawą kulturowych resztek - które rozumiem nie tylko jako pozostałości organiczne, zwłoki, kości, szczątki, ale także jako wszelkie dokumenty materialne i medialne formy przeszłości, takie jak analizowane tu zdjęcie z prapremiery Powrotu Odysa - dochodzi do transformacji pamięci. Nekroperformans traktuję zatem jako narzędzie nowego projektu krytycznej i uhistorycznionej antropologii, który ufundowany został na doświadczeniu Wielkiej Wojny, zapisany zaś w formule teatru nowoczesnego.

Nekroperformans jest sytuacją, w której za sprawą kulturowych resztek w nowych warunkach społecznych i politycznych aktualizuje się historia i materializuje się nie tyle sama przeszłość, ile relacja współczesnych z przeszłością. Ta relacja - jak przekonuje Michael Rothberg - „częściowo determinuje to, kim jesteśmy w teraźniejszości, ale nigdy w sposób niezaprośredniczony, i nigdy bez niespodziewanych czy nawet niepożądanych konsekwencji, które wiążą nas z tymi, których uważamy za innych"30. Dzięki temu nekroperformans pozwala przemyśleć zarówno miejsce powtórzenia w historii, ale także miejsce historii w ramach rytualnego powtórzenia - odgrywa bowiem historię „jako zbiór osadzających się aktów, które nie są same z siebie historyczne, lecz są aktami ustanawiania wszystkich zdarzeń wstecz

Zob. L. Kolankiewicz Dziady... 
- powtarzającymi się aktami ustanawiania pamięci"31. I to właśnie w tej nieustannej aktualizacji tego, co minione, opartej na performowaniu archiwum własnej kultury, widzę szansę na przerwanie zniewalającej siły oddziaływania opartej na resentymencie polskiej pamięci, która w imię pielęgnowania mitu całkowitości narodu i towarzyszącego mu rytuału scalania ciała narodowego przesłania realne problemy socjalne, ekonomiczne i polityczne współczesnego świata. Powróćmy zatem raz jeszcze do fotografii Odysa - odzianego w łachmany, zmęczonego człowieka - wydostającego się z morza na brzeg wyspy, która okazuje się pełną szczątków przestrzenią śmierci. Czy obraz ten - właśnie jako wciąż aktywny obraz kultury śródziemnomorskiej i jako część również polskiej tożsamości - nie powraca dziś w sposób niepokojący i upiornie znajomy?

Powracający dziś na scenę historii obraz Odysa uchodźcy właśnie dlatego, że stanowi część wspólnego doświadczenia nas współczesnych, wywołuje poczucie Niesamowitego. Jak jednak zinterpretować akt rytualnego powtórzenia tego obrazu w teatrze w obliczu dziejącej się realnie katastrofy? Kiedy 6 września 2016 roku w ruinach teatru greckiego, znajdującego się na niemal całkowicie bezludnej wyspie Delos, odegrano przedstawienie Hecuba. ARefugee (Hekabe.Uchodźca), pośród kamiennych resztek na Morzu Egejskim widzowie usłyszeć mogli przejmujący krzyk niewolnicy Odyseusza. Hekabe, która na skutek zdobycia Troi przez wojska greckie straciła męża, króla Priama, oraz wszystkie dziewiętnaścioro dzieci, w spektaklu Nikosa Karageorgosa pojawiła się jako syryjska kobieta opłakująca współczesną tragedię swojego kraju. Niewolnica Odyseusza nie stała się tu jednak ucieleśnieniem biernego cierpienia kobiecego w obliczu trwającej od kilku lat wojny. Grecka aktorka Despoina Bebeli wcielająca się w rolę matki skazanej na nieustanne powtarzanie utraty własnych dzieci, przywołując dwa przedstawienia kulturowe Hekabe: mścicielki z dramatu Eurypidesa, oślepiającej mordercę jednego z jej dzieci, i suki wyjącej na grobie syna z Metamorfoz Owidiusza, przekształciła się w polityczną ikonę zemsty. Jako figura podwójnie Innego - kobiety i muzułmanki - symbolicznie zamknęła zarazem europejską historię kulturowych powrotów Odysa - mężczyzny i żołnierza. Jej rozdzierający krzyk pośród ruin nieużywanego od ponad 2000 lat starożytnego teatru wprowadził ten rodzaj dysonansu poznawczego, który powstaje na skutek ujawnienia się tego, co

R. Schneider Performans pozostaje, przeł. D. Sosnowska, w: RE//MIX. Performans i dokumentacja, red. T. Plata, D. Sajewska, Instytut Teatralny im. Zbigniewa Raszewskiego, Komuna Warszawa, Wydawnictwo Krytyki Politycznej, Warszawa 2014, s. 33. 
obce, w tym, co znane, a powtórzony na scenie teatru - odegrany raz jeszcze jako nekroperformans - odsłonił nieoczekiwane przekształcenia w rozumieniu nas samych i rozpoznaniu Innego.

\section{Abstract}

\section{Dorota Sajewska}

INSTITUTE OF POLISH CULTURE, UNIVERSITY OF WARSAW

UNIVERSITY OF ZURICH

Necro-Performance: The Causative Effect of Fragments in Polish Cultural Memory

Sajewska enters into dialogue with the two principal models of memory in Polish theatre: the Romantic paradigm that universalizes Poland's peripheral status a proposed by Leszek Kolankiewicz in Dziady: Teatr święta zmarłych [Dziady: Theatre of the Feast of the Dead, 1999], and the model based on the parallelism between modernity and the Holocaust as established by Grzegorz Niziołek in Polski teatr zagłady [Polish Holocaust Theatre, 2013]. According to Sajewska, the rivalry between these two grand narratives about the Polish theatre community obscures other historical experiences. Her analysis of the presence of World War I in Polish cultural memory emphasizes the materiality of the allegedly ephemeral body. Negotiating meanings between theatrical historiosophy, anthropology and contemporary theories on the performativity of archives, Sajewska proposes a concept that draws not on the paradigm of the testimony but that of evidence - remains, traces, vestiges. Key to these concepts are the correlated notions of the body-archive and necro-performance. These notions problematize the relationship between the researcher and the archive material, while also suggesting a concrete strategy and practice of writing cultural history.

\section{Keywords}

necro-performance, body, archive, fragments, remains, World War I, Wyspiański 